\title{
ENDOGENOUS PROCESSES OF COLONIAL SETTLEMENT. THE SUCCESS AND FAILURE OF EUROPEAN SETTLER FARMING IN SUB-SAHARAN AFRICA*
}

\author{
EWOUT FRANKEMA \\ Wageningen University ${ }^{\mathrm{a}}$ \\ ERIK GREEN \\ Lund University ${ }^{\mathrm{b}}$ \\ Stellenbosch University ${ }^{\mathrm{c}}$ \\ ELLEN HILLBOM \\ Lund University
}

* Received 21 May 2015. Accepted 20 November 2015. For their comments on previous drafts of this paper, the authors thank the participants of the session on Markets and Trade in Pre-Colonial and Colonial Africa at the Swedish Economic History Meeting 2013 at Lund University, of the seminar Colonial Legacies: Persistence and Long-Run Impact on Economic Growth at Fundación Ramón Areces-Instituto Figuerola de Ciencias Sociales in Madrid, and the session Settler Farming in East and Southern Africa of the African Economic History Workshop 2016 at Wageningen University, as well as colleagues at the Department of Economic History, Lund University and two anonymous reviewers. The authors are grateful for financial support of the Visiting Fellowship Program of the School of Economics and Management, Lund University. Ewout Frankema acknowledges financial support from the European Research Council under the European Community's Seventh Framework Programme for the project «Is Poverty Destiny? A New Empirical Foundation for Long-Term African Welfare Analysis» (ERC Grant Agreement no. 313114); and from the Dutch Science Foundation for the project «Is Poverty Destiny? Exploring Long Term Changes in African Living Standards in Global Perspective»(NWO VIDI Grant no. 016.124.307). Erik Green acknowledges financial support from the Swedish Research Council for the project «Development or exploitation: Mapping the development trajectories of large-scale farming in Kenya, Malawi, South Africa and Zimbabwe (Dnr: 2014-1509).

a Department of Social Sciences, Rural and Environmental History Group, Wageningen University, Hollandseweg 1, 6700 EW, Wageningen, The Netherlands. ewout.frankema@wur.nl

b School of Economics and Management, Department of Economic History, Lund University, PO Box 7083, 22007 Lund, Sweden. erik.green@ekh.lu.se; ellen.hillbom@ekh.lu.se

c Department of Economics, Stellenbosch University, Private Bag X1, Matieland, 7602, South Africa. erik.green@ekh.lu.se 


\begin{abstract}
This paper comments on studies that aim to quantify the long-term economic effects of historical European settlement across the globe. We argue for the need to properly conceptualise "colonial settlement» as an endogenous development process shaped by the interaction between prospective settlers and indigenous peoples. We conduct three comparative case studies in West, East and Southern Africa, showing that the «success» or «failure» of colonial settlement critically depended on colonial government policies arranging European farmer's access to local land, but above all, local labour resources. These policies were shaped by the clashing interests of African farmers and European planters, in which colonial governments did not necessarily, and certainly not consistently, abide to settler demands, as is often assumed.
\end{abstract}

Keywords: Sub-Saharan Africa, colonial history, settler farming, cash-crop production

JEL Codes: N01, N17, O10, O13

\title{
RESUMEN
}

Este trabajo hace un balance de los estudios que tienen por objeto cuantificar los efectos económicos a largo plazo de la colonización europea histórica en el mundo. Se defiende la necesidad de conceptualizar adecuadamente «asentamiento colonial» como un proceso de desarrollo endógeno determinado por la interacción entre los potenciales colonos y los pueblos indígenas. Se llevan a cabo tres estudios comparativos de caso en el oeste, el este y el sur de África, mostrando que el "éxito»o "fracaso» del asentamiento colonial dependía fundamentalmente de las políticas que el gobierno colonial organizase para el acceso del agricultor europeo a la tierra local, pero sobre todo, a los recursos de mano de obra local. Estas políticas se determinaron por los intereses en conflicto de los agricultores africanos y los granjeros europeos, y los gobiernos coloniales, en contra de lo que frecuentemente se supone, no acataron necesariamente (y desde luego no de manera consistente) las demandas de los colonos europeos.

Palabras clave: África subsahariana, historia colonial, agricultura de colonos, producción de cultivos comerciales 


\section{INTRODUCTION}

Historical colonial settlement, that is, the permanent settlement of foreign peoples in overseas territories under some form of imperial control, constituted a "process», not an «event». The long-term development outcomes of historical colonial settlement have been simultaneously shaped by the agency of the settlers and of the indigenous peoples living in the "receiving areas». The initial «success» of colonial settlement was important for subsequent waves of settlement, and indeed, for the evolution of settler colonies in general. Colonial settlement processes thus evolved endogenously.

Although these statements may all appear to be commonplace, this is not the way "colonial settlement» is conceptualised in an influential strand of literature that has tried to quantify the long-term economic effects of historical European settlement across the globe (Acemoglu et al. 2001, 2002; Putterman and Weil 2010; Easterly and Levine 2012). These studies maintain that a substantial part of current world GDP results from historical transfers of technology, human capital and capitalist or developmental institutions from Europe towards non-European areas, and that these transfers were stronger in areas experiencing larger shares of permanent European settlement. The key statistic underpinning this view is that places where Europeans have settled in large(r) numbers are significantly richer today than places where they have not.

This paper does not intend to dispute the correlation between quantified levels of historical settlement and present-day income levels, but rather to critique some of the implicit assumptions of this literature regarding the nature of colonial settlement processes. From this critique it will follow that the standard causal narrative discussed above contains serious flaws. Our first concern is that colonial «settlement» in these studies is measured as if it were an event. By taking the average share of European settlers over the total population at a given point in time (Putterman and Weil 2010; Easterly and Levine 2012), or by taking a proxy variable such as historical settler mortality rates (Acemoglu et al. 2001, 2002), colonial settlement is reduced to a single-level variable. This is useful for running regressions, but comes at the expense of time-variant process characteristics of colonial settlement.

Our second and related concern is that the meta-narrative of these studies tends to consider "settlement» as the result of conditions that are exogenous to the settlement process itself. European preferences for settlement are regarded as a function of local ecological conditions, tropical diseases or local resource endowments. In practice, however, settlement processes were endogenous: developments in the early phases of colonial settlement either encouraged or discouraged later waves of colonial settlement, and also determined the institutions governing the allocation of resources between 
settlers and indigenous peoples. The ways in which the political and economic interests of European settlers and indigenous peoples were politically mediated were crucial for the direction of these "paths» of colonial settlement. These paths, as we will show, cannot be properly understood if transfers of technology, human capital and institutions are considered as a unilateral transmission from Europe to the rest of the world. Indigenous agency played a key role in transfers of economically valuable knowledge and technology, and institutions governing the allocation of resources and arranging the distribution of power were influenced by settlers and indigenous inhabitants alike.

Although we are not the first to comment on Eurocentric accounts of global inequality (Austin 2008; Bayly 2008; Hopkins 2009; Frankema and van Waijenburg 2012; Austin and Sugihara 2013; see for a recent critique by economists: Banerjee and Duflo 2014), the critique we develop in this paper takes a different angle than previous studies have taken. We start with the question what exactly constitutes a «settler colony»? We argue that this question is not so easy to answer. Quantitative measures of colonial settlement, such as the percentage share of Europeans in the total population living in an overseas area at a particular point in time, contain several implicit, but disputable, assumptions on the nature of colonial settlement and the causality underpinning the supposed transmission channels from European settlement to long-term economic development. After discussing the issue of conceptualising colonial settlement, we will review these channels of transmission.

In the second part of the paper we proceed with three comparative case studies in West, East and Southern Africa in which we explore the factors of success and failure of European settlement in greater detail. Settler farmers constituted by far the largest group of permanent European settlers in Sub-Saharan Africa and were thus crucial to the evolution of settler colonies in this part of the world. These case studies supplement our critique with an alternative interpretation of historical settlement processes in Sub-Saharan Africa, as they reveal that the viability of settlement critically depended on colonial government policies arranging access to local land, and above all, local labour resources. These government policies were, in turn, shaped by the clashing interests of African farmers (mainly smallholders) and European planters, in which colonial governments did not necessarily, nor consistently abide to settler demands, as is often assumed.

We introduce the term endogenous processes of colonial settlement to underline the Eurocentrism inherent to studies that conceal the agency of indigenous peoples in this process to a set of (discrete) control variables in regression analyses. We hope that this term will inspire more in-depth studies of colonial settlement processes and more careful interpretations of the historical causality running from settlement processes to long-term processes of economic development. 


\section{WHAT CONSTITUTES A «SETTLER COLONY»?}

A solid understanding of the long-term development legacies of colonial settlement should always start with the question of definition: What exactly constitutes a "settler colony»? This question is not only relevant to studies looking at the global historical settlement-development relationship; in the long-standing debate on colonial legacies in Africa, the distinction between «settler colonies» and so-called "peasant export colonies» also frequently surfaces as an important explanatory factor (e.g. Amin 1972; Mosley 1983; Bowden et al. 2008; Mkandawire 2010). A popular way to approach the question of definition is to measure "colonial settlement» as the percentage share of European settlers in the total population at a given point in time. This is the approach taken by Easterly and Levine (2012) in their article with the unambiguous title The European Origins of Economic Development (see also Putterman and Weil 2010) ${ }^{1}$. To start thinking about ways to define a «settler colony» it is worthwhile to explore what such a definition captures and what it does not.

Let us take the United States as an example of a prototype «settler colony». «Settlement» in what was to become the United States involved large numbers of European settlers crossing the Atlantic since the early $17^{\text {th }}$ century. Historical settlement in the United States also involved considerable numbers of Africans who were forced to «settle». Surprisingly or not, in Easterly and Levine's measure of colonial settlement, it is only the European settlers that are included in the numerator. African slaves and their offspring are included in the denominator. Since the central hypothesis of Easterly and Levine is that historical European settlement «causes» higher levels of long-term development, adding African «settlers» to the denominator indeed appears to be in line with their hypothesis that European settlers are key in enhancing long-term economic growth. But this quantification strategy also involves an implicit judgement, namely that the contribution of African settlers to U.S.'s long-term economic development was negative. Our point is that the interaction between both categories of «settlers», slaves and slave owners, was important to the long-term development of the U.S. economy, but that this interaction is neglected in their analysis.

If the aboriginal population had survived European germs and military technology in large numbers, the United States may never have become a prototype «settler colony». This points to another aspect of settlement "processes». Although the term suggests a transfer of people from one area to another, "settler colonies» have been shaped as much by flows of permanent migrants, as by the relative capacity of indigenous population to resist

${ }^{1}$ It is interesting to note that Easterly (2006) is very positive about the long-term effects of European settlement in this study, while being highly critical of the West's efforts to aid the «rest» in the 20th century. 
foreign encroachment, either by staying alive and reproducing, or through active opposition against foreign settlement. The key issue here is that settler shares evolve over time and are shaped by numbers of settlers and indigenous peoples, but that the causal narrative just takes the denominator for granted.

Let us now consider what relative numbers (percentage shares of settlers), as opposed to absolute numbers, imply for the design of historical hypotheses. There are cases where colonial settlement was considerable in absolute numbers, but dwarfed by the numbers of indigenous peoples that happened to live within the borders of the said colony. With c. 62,000 Europeans in 1900, the Dutch East Indies cannot really be called a «settler colony» in relative terms (a share of c. 0.2 per cent), but in absolute terms it may be expected that this group of settlers was capable of leaving a much larger imprint than the c. 400 European settlers in Malawi in the 1920s, who constituted a comparable minority in relative terms. Similar arguments can be made for other colonies, for example, British India.

The problem grows bigger when people in the numerator and denominator produce joint offspring. In Latin America, the gradual mixing of settlers with indigenous peoples poses a problem for the adequate measurement, and indeed for the very definition of, European settlement levels. Not only does the timing of the observation become a crucial factor in the recorded intensity of settlement, but as European settlers intermingled with indigenous peoples and other immigrant populations (i.e. African slaves), pure «settlers» also quickly became a minority (Elliott 2006). This begs the question whether settler colonies can stop being settler colonies at some point in time? Put differently, how «European» are the origins of Latin American economic development?

For Africa the term "settler colony» has another connotation, for European settlers never constituted a majority of the population, nor did they intermingle with locals on a large scale. But do small shares of settlers mean that the term African «settler colony» is an aberration? It is worthwhile contemplating a more qualitative classification of African colonies, as was originally done by Amin (1972). In his view, African «settler colonies» refer to colonies where the majority of the cultivable land had been appropriated for European use; "peasant colonies» refer to colonies where land remained in African hands; and «concession colonies» were colonies where large shares of the land were reserved for European mining or plantation companies rather than individual settler farmers. Hence, Amin's definition of a «settler colony» does not take the shares of Europeans vs. Africans into account, but instead stresses a qualitative feature: a «settler colony» is a colony in which the colonial government appropriates and reallocates productive resources to colonial settlers on a significant scale (see also Mosley 1983, p. 5). Austin (2015) has coined the term «settler-elite colony» to indicate that in all African colonies Europeans remained a (tiny) minority, but that in some 
cases this minority intervened in local markets for land and labour much more intensively than in others ${ }^{2}$.

In sum, qualitative definitions of a settler colony may deviate substantially from quantitative definitions, but where the former considers the political context governing the settlement process and the allocation of resources, the latter exclusively focusses on relative shares of settlers.

\section{CHANNELS OF TRANSMISSION}

The supposed causal mechanisms running from historical European settlement in overseas areas to current development outcomes (be it GDP or other indicators) are not uncontested. Whereas Easterly and Levine (2012) and Putterman and Weil (2010) emphasise the positive contribution of transplanted European technology, human capital and institutions in line with Rostow's (1960) outlook on the global diffusion of capitalism; Acemoglu and co-authors have, in line with dependency theorists like Rodney (1972), put much more emphasis on the negative role of so-called «extractive» or «exclusive» colonial institutions in areas without significant European settlement, arguing that the institutional legacies of European imperialism have put large parts of the Southern hemisphere at a greater distance than they otherwise would have been (Acemoglu et al. 2001, 2002; Acemoglu and Robinson 2010, 2012). The common thrust of all these studies is that larger shares of European settlers, or the disappearance of indigenous peoples for that matter, enhance long-term economic growth.

At face value, Africa's comparatively low degree of European settlement and lagged economic development seems to suit either of the two metanarratives quite well. With the exception of the southernmost part of the African continent, the bulk of European settlers in Sub-Saharan Africa arrived in a fairly short timeframe between 1900 and 1960. Europeans never settled in numbers large enough to become a majority. The share of Europeans in settler colonies like Kenya, Zambia, Zimbabwe or the Congo remained (far) below 10 per cent. Only in South Africa the white minority constituted around one-fifth of the total population at the start of the $20^{\text {th }}$ century. And yes, Africa is the poorest region of the world at present. So, either Africa is poor because of extractive colonial institutional legacies or because of the comparative absence of European settlers transferring economically valuable knowledge and technologies ${ }^{3}$.

${ }^{2}$ It should be noted that the term «settler-elite colony» is difficult to maintain for South Africa, where a substantial part of the white minority lived in abject poverty, people of European descent who could only be considered as part of the «elite» in so far they had voting rights, which indigenous Africans had not.

${ }^{3}$ It should be noted that within Africa, the supposed correlation between European settlement and long-term economic development is not so evident. Although per capita GDP levels in «settler 
Easterly and Levine (2012) present a global cross-country regression «showing» that 47 per cent of current global income levels, expressed in average GDP per capita of 1995-2005, is attributable to historical European settlement alone. They identify «technology transmissions» as the single most important mechanism in explaining the contribution of European settlers to late $20^{\text {th }}$ century income levels. The suggested productivityenhancing effects of access to advanced European technologies range from the guns and steel that were essential to establishing Spanish law and order in the Americas (Diamond 1998), to a plethora of agrarian, mining, transportation and communication technologies facilitating the commercial exploitation of various types of resource-based commodities across European empires. For Sub-Saharan Africa, this view is consistent with a long-dominant paradigm of inert African agricultural societies professed by the early explorers, missionaries and colonial officers in the late $19^{\text {th }}$ and early $20^{\text {th }}$ centuries. In this paradigm, «traditional» African agriculture had been captured in a static equilibrium with its natural environment, a situation which could only be changed by external that is colonial, economic interventions (Niemeijer 1996, pp. 87-88).

Another transmission channel that has received ample attention is the diffusion of European or Western education, skills and knowledge via investments made in schooling by colonial governments and Christian missionaries (Gallego and Woodberry 2010; Nunn 2010; Woodberry 2012; Fourie and von Fintel 2014). These studies suggest that the presence of European missionaries and settlers had a positive effect on the development of literacy and school enrolment rates, as well as on the transmission of specific economic skills. This literature tends to emphasise, in line with the popular account of Ferguson (2002), that British colonial rule was more «developmental» than that of other European powers (see Frankema 2012 for a critique).

A third transmission channel relates to the idea that the presence of European settlers shaped the incentive structures of colonial states to adopt specific institutional arrangements to govern colonial societies. In «settler colonies» the so-called «developmental» or «inclusive» institutions guaranteed broad access to economic and political markets, secured property rights

\footnotetext{
(footnote continued)

colonies» such as South Africa, Zimbabwe, Zambia and Kenya have, on average, been somewhat higher than in the "non-settler colonies» throughout the post-colonial era, there is no evidence that the living standards of indigenous Africans were significantly higher (Bowden et al. 2008; Moradi 2008; de Zwart 2011; Frankema and van Waijenburg 2012). Moreover, it is important to ask what exactly constitutes «long-run» development? If comparative levels of GDP per capita are the yardstick, then it is worthwhile noting that the relative ranking of Sub-Saharan African countries has changed considerably after independence. In a sample of forty-two mainland countries South of the Sahara, the "settler colony» Zimbabwe ranked ninth in 1990 to fall back to the thirtieth position in less than two decades (Maddison 2010). An even more dramatic collapse can be noted for the "semisettler colony» of Belgian Congo.
} 
and used tax revenues for the provision of development-enhancing public goods, as European settlers were used to at home. In colonies without such demands from European settlers, colonial governments designed «extractive» or "exclusive» institutions that facilitated the extraction of resources (Acemoglu et al. 2001, 2002).

In more recent work Acemoglu and Robinson have modified their original account, arguing that in some colonial societies' dual institutional structures emerged: inclusive institutions were «exclusively» reserved for European settlers, while «exclusive» institutions determined the rights and obligations of the indigenous peoples. South Africa's apartheid system is the key example of such a dual institutional structure, which forged indigenous Africans into a readily exploitable source of cheap labour, by denying private property rights to land as well as the right to free movement, high-quality public services and national political representation (Acemoglu and Robinson 2012, pp. 258-271).

What binds these narratives together is that the transmission channels are all considered to have been exogenously imposed by European settlers, who transplanted technologies, human capital and institutions from Europe to overseas areas. Such Eurocentric conceptions of unilateral transmission channels have invoked ample criticism. Carney and Rosomoff (2011) have argued that the agrarian technologies and crop cultivation knowledge brought by African slaves to the New World were vital to the supplies of food to slave plantations, but that this part of the Columbian exchange has never been seriously contemplated in the literature. In a recent edited volume on Labour-Intensive Industrialization in Global History, several leading economic historians explore the extent to which Western technology transfers after 1800 merged with local paths of technological development in East Asia and other parts of the world (Austin and Sugihara 2013; see also Frankema 2015). They show that in so far industrial technologies diffused from the "West» to the «rest», local paths of economic development conditioned the pace of adaption, as well as the extent to which these technologies were transformed to suit local economic circumstances. European settlers play a role in this, no doubt, but local endowment structures and state institutions appear as the main determinants. In a more balanced account, Putterman and Weil (2010) incorporate a measure of «state antiquity» in their explanatory analysis of global inequality and find that nonEuropean histories also matter. But their analysis stops where it really gets interesting: the interaction between European settlement processes and the strength/qualities of local state institutions.

Another idea that has received ample criticism is that in areas without European settlement, European imperial powers were capable of imposing institutions via "absolutist» colonial regimes (Young 1994; Acemoglu et al. 2001, p. 1375). Colonial governments in the non-settler colonies had recourse to just a handful of European administrators who depended on the 
cooperation of local chiefs in such important domains as tax collection, rule of law, labour recruitment and army services (Austin 2008; Bayly 2008; Hopkins 2009; Frankema 2011; Gardner 2012; Storm 2013). Kirk-Greene (1980) has called it the "thin white line» and Cooper (2002) has coined the term "gate-keeper state» to refer to the minimalistic type of colonial government. In a similar vein, Frankema (2012) has criticised the notion that the missionary movement in Africa was a white European movement, showing that the far majority of missionaries involved in mission schools were of African origin and were maintained by African resources, begging the question really how much of the supposed «knowledge» transfers went unilaterally from Europeans to Africans.

A final line of critique that has not received the attention it deserves is that the Eurocentric conception of the relationship between historical settlement and these transmission channels contains a serious flaw in the order of causation. Why would European settlement have been a pre-condition for the transfer of growth-promoting technologies, knowledge and institutions? Isn't it the other way around, namely that the initial productive success of European institutions, knowledge and technology in alien ecological, economic and political contexts determined European settlement?

A counterfactual thought-experiment helps to clarify this point: What if Europeans would have settled in large numbers in Western Africa from the early $16^{\text {th }}$ century onwards to set up slave plantation economies with locally sourced slaves, instead of shipping African slaves across the Atlantic? This thought-experiment is not as odd as it may appear, because this is exactly what European venture capitalists tried first, setting up slave plantations on islands close to the African coast, such as Madeira, São Tomé and Príncipe (Klein 2010, p. 10; Seibert 2013). Why did Europeans not expand the slave plantation systems to the Sub-Saharan African mainland? It would obviously have saved transportation costs and severe losses of costly (human) cargo.

Historians have stressed two distinct reasons. Some maintain that ecological conditions (soil qualities, disease climates) were more favourable in the New World and that American plantations just turned out to be more productive. Others have stressed that Europeans found it much easier, and thus cheaper, to control land and African labour in the Americas, than in Africa itself (Eltis 2000; Law 2013). Indeed, transplanting African slaves to an alien and distant environment eliminated the risk of local resistance against European plantations and it also reduced the risk of slave uprisings by limiting chances of survival and protection outside the plantations. Slave owners also found it easier to control slaves in an environment where they had a monopoly on guns, which they clearly did not have in West Africa, as guns and gunpowder were crucial means of exchange in the acquisition of slaves.

No matter how one weighs these factors, the bottom line is that prevailing European technologies, human capital and institutions were not suited for controlling considerable land and labour resources in tropical Africa and this 
pretty much remained the case up to the scramble for Africa in the late $19^{\text {th }}$ century. The absence of European settlers was a consequence of this mismatch, not a cause. So if one wants to maintain the idea that European technologies, knowledge and institutions were key in supporting long-term economic growth, one has to confront the question why these technologies were much more effective in controlling productive resources in some areas than in others in the first place. Indeed, this question can only be addressed if one is prepared to leave the trenches of Eurocentrism.

\section{EUROPEAN SETTLER FARMING IN COLONIAL AFRICA}

The settlement of European farmers in Sub-Saharan Africa in the early $20^{\text {th }}$ century offers a factual historical lens to study the mechanisms driving endogenous processes of colonial settlement. Settler farmers constituted by far the largest group of permanent settlers, because European government employees, merchants, missionaries or Asian migrant workers mostly settled on temporary base. Settler farmers also posed clearly identifiable demands on colonial governments: access to land and local sources of labour. Given the relative scarcity of labour and the relative abundance of land in most of Sub-Saharan Africa, it was much easier to secure large tracts of uncultivated and uninhabited land, than to force indigenous peoples with alternative means of subsistence into working (parts of) this land against their will (Amin 1972; Mosley 1983; Austin 2008). Land alienation was therefore often used as a complementary strategy of labour commodification. As colonial authorities held the key to legal and military sanctions, European settlers depended on governmental support to back-up their claims to land and labour. In colonies with considerable mining sectors, such as Southern Rhodesia, settler farmers often faced severe competition from mining companies with similar interests in manual labour supplies.

To structure our analysis we adopt a simple framework of the political context of the settlement process of European farmers in colonial Africa. Figure 1 proposes that the success of European settlement depended on how the colonial government resolved the conflict of interest between African farmers and (prospective) European planters. Local ecological conditions and food production systems gave a distinctive dynamic to conflicts over land and labour. Possibilities of intercropping or double cropping, the allocation of family labour and the seasonal cultivation cycles were central to the interest of African farmers in taking up commercial crops, and to engage in direct competition for export markets, land and labour with European settler farmers. The response of African farmers thus co-determined the degree of coercion that colonial governments had to enforce (by legal and practical means) to help settler farmers to sufficient supplies of (seasonal) rural labour. 
FIGURE 1

THE POLITICAL CONTEXT OF EUROPEAN SETTLER FARMING IN COLONIAL AFRICA

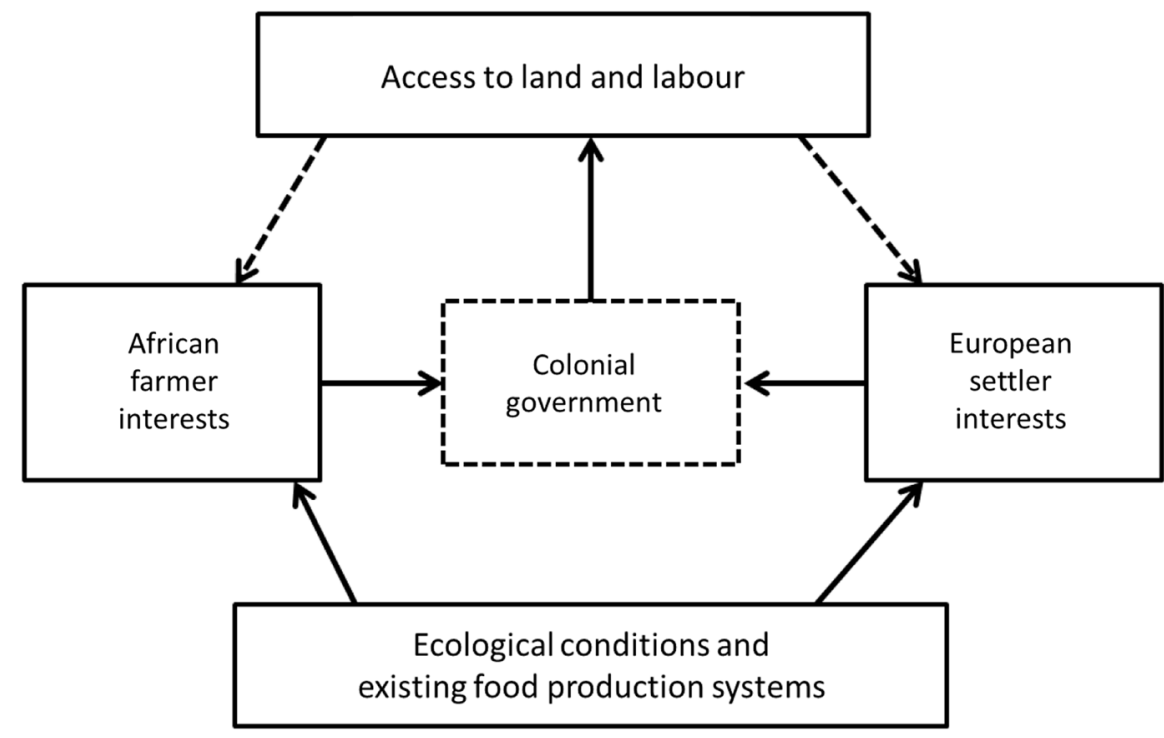

Source: The authors' own.

Not all colonial authorities were willing to, or merely capable of, coercing Africans into wage or contract labour. In case African farmers successfully engaged in the production of export crops, the incentives to concede to settler demands became weaker and in some cases governments would go as far as to entirely prohibit European land ownership. Moreover, colonial government policies were far from static. They could switch from facilitating European settler farming towards encouraging African smallholder production if changing economic or political circumstances gave reason to do so. Especially when government revenues came under pressure from declining exports, during the Great Depression of the 1930s, colonial governments reconsidered the restrictions they had put on African smallholders engagement in cash-crop production.

We are aware that this framework offers an overly simplified account of the political context of the settlement process, but it helps us to focus on the interaction between European settlers, African farmers and government policies of resource allocation, and to explore the conditions of settlers' «success». We define «success» as a substantial long-term growth of commercial crops produced by European farmers, and/or a growing number of farmers engaged in the export sector absorbing a growing share of 
land and/or local labour. Settler farming «failed» in case African smallholders' engagement in cash-crop production prevented the growth of the European sector from the beginning, or in case of a substantial and permanent decline in settler farmers' output and exports, after an initial expansion.

\section{THREE COMPARATIVE CASE STUDIES}

Our three comparative case studies are located in different parts of SubSaharan Africa, with different ecological conditions for the production of commercial crops: cocoa in the Gold Coast (present-day Ghana) and Ivory Coast (West Africa), coffee in Kenya and Tanganyika (present-day Tanzania) (East Africa), and tobacco in Nyasaland (present-day Malawi) and Southern Rhodesia (present-day Zimbabwe) (Southern Africa). All three crops were primarily grown for European export markets. They could all be grown successfully on large estates as well as on small family farms, as they do not require large capital investments beyond the scope of smallholder producers (Haviland 1954; Barlow and Jayasurija 1986; Orr 2000; Curtis 2003). Our cases are also selected within a uniform timeframe (c. 1900-1960). These cases thus enable us to analyse the conflicts of interest between African farmers and European farmers, and the way colonial governments mediated these conflicts by regulating access to land and labour. In doing so, they offer a deeper insight in the nature and evolution of colonial settlement in Sub-Saharan Africa.

\subsection{Coffee Farming in Kenya and Tanganyika}

The East African Highlands offer a favourable climate for coffee cultivation. In the spirit of «Christianity and commerce», European missionaries initiated coffee production in the area in the 1890s, spreading the crop and sharing techniques with African farmers (Spear 1997; Curtis 2003; Eckert 2003). For the African farmers coffee required a relatively light labour input, it was suitable for intercropping with plantains, the primary staple crop (Tosh 1980), and thus formed an attractive opportunity to raise cash earnings. Settler farmers also regarded large-scale coffee production as a profitable proposition. In the Kenyan Eastern and Central Highlands settlers were of mixed origin, with the majority being of British or South Africans of British decent. Meanwhile, German and Boer settlers were invited to the northern part of Tanganyika by the German administration (1896-1919). From the turn of the $20^{\text {th }}$ century African farmers and settler farmers competed for land and labour to produce coffee.

As Figure 2 shows, there was a steady and sharp growth of coffee exports from roughly the early 1920 s, peaking in the mid-1930s with close to 20,000 
FIGURE 2

COFFEE EXPORTS (TONNES) FROM KENYA AND TANGANYIKA (1900-1960)

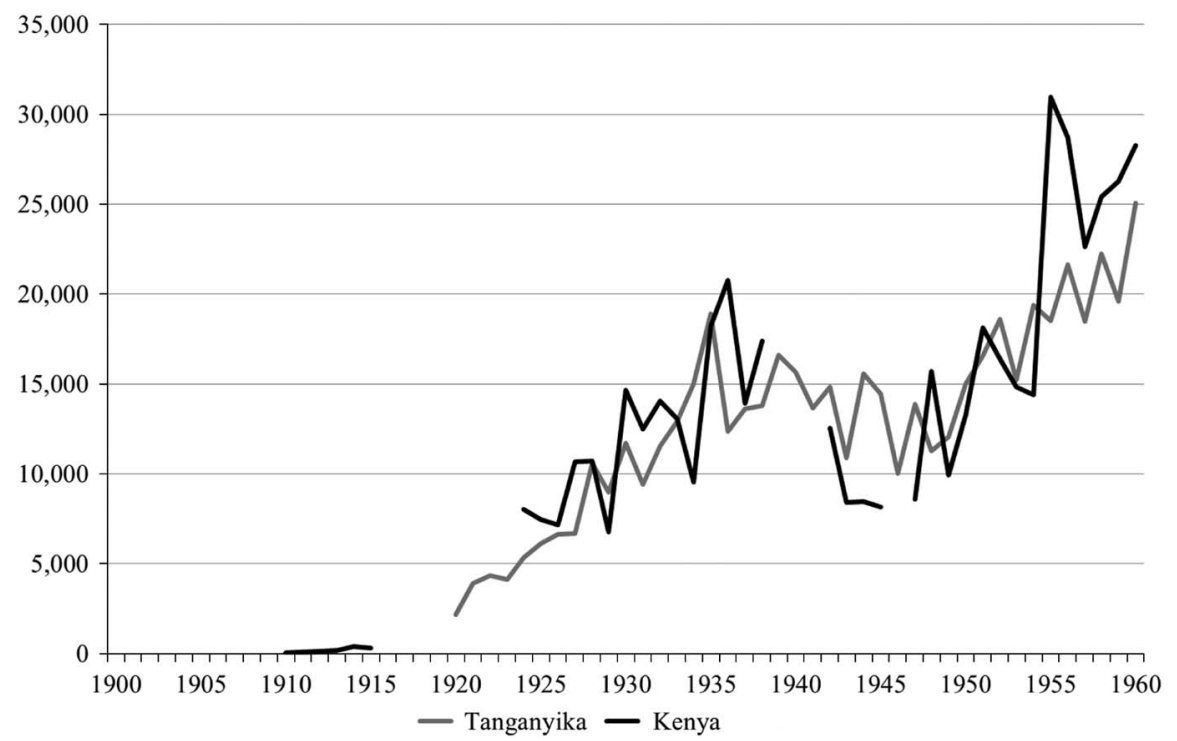

Sources: 1900-1945 from the Blue Books of Kenya and Tanganyika, TNA CO 543/1-36 and CO 726/1-30, respectively; 1945-1960 from reports of the Agricultural Department in the Sessional Papers of Kenya and Tanganyika, TNA CO 544/61-101 and CO 736/25-62, respectively.

tonnes in both colonies. This was followed by a slump during the Second World War, which was eventually overcome in the 1950s. However, the processes of colonial settlement diverged. In Tanganyika, indigenous production complemented settler production from the start and already in the 1920s African producers came to dominate the sector. In Kenya the production of coffee was dominated by the settler community, and opportunities for Africans came later and were more piecemeal so that it was not until the 1950s that indigenous production overtook settler production. The key difference was that the settler community in Kenya was small, but politically potent and successful in lobbying for an almost complete ban on indigenous coffee production from the time of colonial establishment in 1895. Rather than producing cash crops, the indigenous population was expected to provide labour for colonial endeavours such as infrastructure projects, work as farmhands on settler estates and produce food either for the domestic market or for the administration to feed the growing group of African wage labourers (Hyde 2009).

The German administration in Tanganyika was initially more hesitant to allow European settlement in fear of conflict with indigenous Africans, but 
increasingly perceived white settlement as a pre-condition for the development of the colony, following the example of the British administration in Kenya (Iliffe 1979, Ch. 5). Yet, contrary to Kenya, indigenous coffee production was never prohibited. In 1922, after Germany's defeat in the First World War, Tanganyika became a League of Nations Mandate under Britain. The mandate stipulated that Tanganyika had to be governed as an "African» country. While Britain was granted full legislative and administrative powers, she had to commit to promoting the well-being of African subjects, which included protecting them from the expropriation of land and the coercion of indigenous labour. The existing indigenous coffee sector was encouraged, also in areas where European coffee estates had been established. In time, a substantial part of government revenues were provided by market-oriented African smallholders relying on family labour (Iliffe 1979, Ch. 9; Spear 1997; Curtis 2003; Eckert 2003). Meanwhile, the remaining coffee estates had to resort to engaging (distant) migrant workers, rather than local labour (Iliffe 1979, Chs 6 and 9; Spear 1997).

The two British colonial administrations thus developed diverse strategies for settlers' and indigenous farmers' access to land and labour. In Tanganyika the German administration had already been more restrictive in alienating land for white settlement, but with the League of Nations Mandate these restrictions hardened and African farmers were actively encouraged to engage in cash-crop production along with their subsistence crops (Anderson 1984; Curtis 2003). In Kenya, Native Reserves were established to limit Africans' access to land as well as the free movement of people, thereby accommodating settlers' interests in a steady supply of landless labourers. Judging from Mosley's (1983, table 4.4) estimates these policies were generally successful as the labour supply was mostly higher than demand from the 1920s onwards. Notwithstanding, official government reports from the Labour Department kept voicing complaints about chronic labour shortages for European employers.

The Great Depression hit the Kenyan settler farmers hard, resulting in increased unemployment for African farm workers and a severe cutback in the administration's revenues. Between 1928 and 1934 custom duties dropped by ca. one-third (Frankema 2011). This shock forced the Kenyan administration to re-evaluate its support to the settler farmers and instead embark on a more diversified strategy of co-encouraging settler and indigenous coffee production. While the economic crisis also hit custom revenues in Tanganyika, market volatility was largely absorbed by the African smallholders, who were better capable of adapting their production decisions. Inspired by the experiences in Tanganyika, where problems of unemployed and landless plantation workers did not occur, the Kenyan administration reconsidered its ban on indigenous coffee production (Anderson and Throup 1985). In 1935, a small «elite» of African farmers were permitted to start producing coffee, although not in the White Central 
Highlands where European coffee estates dominated. The idea was to concentrate African production in areas where advisory services and supervision were provided. Until 1946 the rate of expansion was curtailed, but as the colonial administration wanted to take advantage of the post-war boom in coffee prices, indigenous production was allowed in an increasing number of areas outside the White Highlands.

It also became increasingly clear during the 1930s that the Kenyan Native Reserves were too small to support a rapidly growing population (Mosley 1983, table 3.3). However, the settler community opposed the idea of granting more land to Africans (Anderson 1984, 2000). It feared indigenous farmers' involvement in cash-crop production and a decline in the supply of African farmhands. But its bargaining power had weakened. Not only the adverse economic circumstances, but also the wider shifts in imperial philosophy towards a more «development-oriented» policy agenda and the African involvement in the military campaigns of Second World War, induced a relaxation of coercive labour market institutions. The Swynnerton Plan of 1954 was a real blow to the political muscle of settler farmers, as it gave indigenous cash-crop producers an almost level playing field. The new ambition was to double coffee production by supporting two groups of producers: European estates using the African proletariat (landless poor) for wage labour, and the indigenous family farms moving from, or combining, subsistence production with commercial agriculture (Hyde 2009).

Both cases clearly reveal that there existed no direct causal link between European skills and technology, on the one hand, and the performance of settler agriculture, on the other. Settler production could only be superior as long as it was protected and given advantages in access to land and labour by the colonial administration and this was not guaranteed. Instead, the amount of support granted by the administration, as well as the timing of the change in government policies regarding the rights of production of African smallholders, depended on the political position of each settler community. While in Kenya the settler community from the beginning amassed sufficient power to steer government policies in the direction of becoming a «settler colony» according to Amin's definition, the initial position of indigenous farmers was stronger in Tanganyika. After the British were handed Tanganyika under the League of Nations Mandate they encouraged indigenous production in response to observable successes of African farmers. The failure to handle international competition of the settler sector in Kenya as well as the downturn accompanying the Great Depression caused the administration to change its strategy. From the 1930s onwards it increasingly followed the Tanganyika example releasing land and labour resources to indigenous farmers. This strategy was re-enforced as it showed positive results. Indeed, this case clearly shows that divergent "paths» of settlement were endogenous to the agency of both settlers and Africans (Makana 2009). 


\subsection{Tobacco Farming in Southern Rhodesia and Nyasaland}

Tobacco became one of the key export commodities of Nyasaland and Southern Rhodesia during the colonial era. It could be grown successfully by smallholders as well as large-scale farmers. Although tobacco was not suitable for intercropping, it grew well in rotation with groundnuts and investments paid off within a single year (Orr 2000, p. 351). The low investment costs enabled smallholders to adjust to volatile market prices by moving in and out of tobacco production on an annual basis. Tobacco was grown, from the start, by white settlers located in the Northeastern region of Southern Rhodesia and the Shire Highlands of Southern Nyasaland. However, the outcomes were strikingly different. While white settler agriculture in Nyasaland failed, the European farmers in Southern Rhodesia continuously expanded their operations throughout the period of our study.

The initial purpose of the British South Africa Company's expansion into the area later known as Southern Rhodesia was to search for gold, but by 1907 the company's directors officially announced that they had failed to find any major gold reefs (Rubert 1998, p. 1). The focus shifted towards establishing a prosperous white farming settler community instead. By 1904 there were 545 European farmers and by the mid-1920s their numbers had increased to, and stabilised at, about 2,500 (Phimister 1988, p. 61). Circa 25 per cent of the settlers arriving before 1920s came from the Union of South Africa, while c. 70 per cent had their origin in Britain (Schutz 1973, p. 7). Figure 3 shows the progress of European tobacco farming. Both volume and acreage under production expanded continuously throughout the colonial era and remained dominated by settler farmers who had successfully managed to turn the colony into the main producer of tobacco in Africa.

Just as in Southern Rhodesia, tobacco was introduced as a settler crop in Southern Nyasaland during the early colonial period, but it never became a success. As Figure 4 shows, from the mid-1920s onwards, European settler production of tobacco declined in absolute numbers as well as in relation to African production. In 1921 there were 399 settler farmers, but by 1931 the number had decreased to 290 and in 1945 there were only 171 settler farmers left; most of these farmers eventually substituted tobacco for tea (Palmer 1985, p. 213). In other words, Nyasaland never became the settler colony that the first governor had foreseen in the late $19^{\text {th }}$ century (Palmer 1985, p. 213). Instead, African smallholder farmers took over the bulk of tobacco production in Nyasaland, turning the protectorate into the third largest exporter of African tobacco in Sub-Saharan Africa, and the largest producer of African grown tobacco (Haviland 1953, 1954).

Why was European tobacco farming so successful in Southern Rhodesia and not in Nyasaland? Colonial policies played a crucial role in mediating access to land and labour in both colonies. In Southern Rhodesia farmers successfully lobbied for restricting African farmers' engagement in commercial 
FIGURE 3

OUTPUT (LB, LEFT-HAND Y-AXIS) AND ACREAGE (HA, RIGHT-HAND Y-AXIS) UNDER TOBACCO IN SOUTHERN RHODESIA (1904-1959)

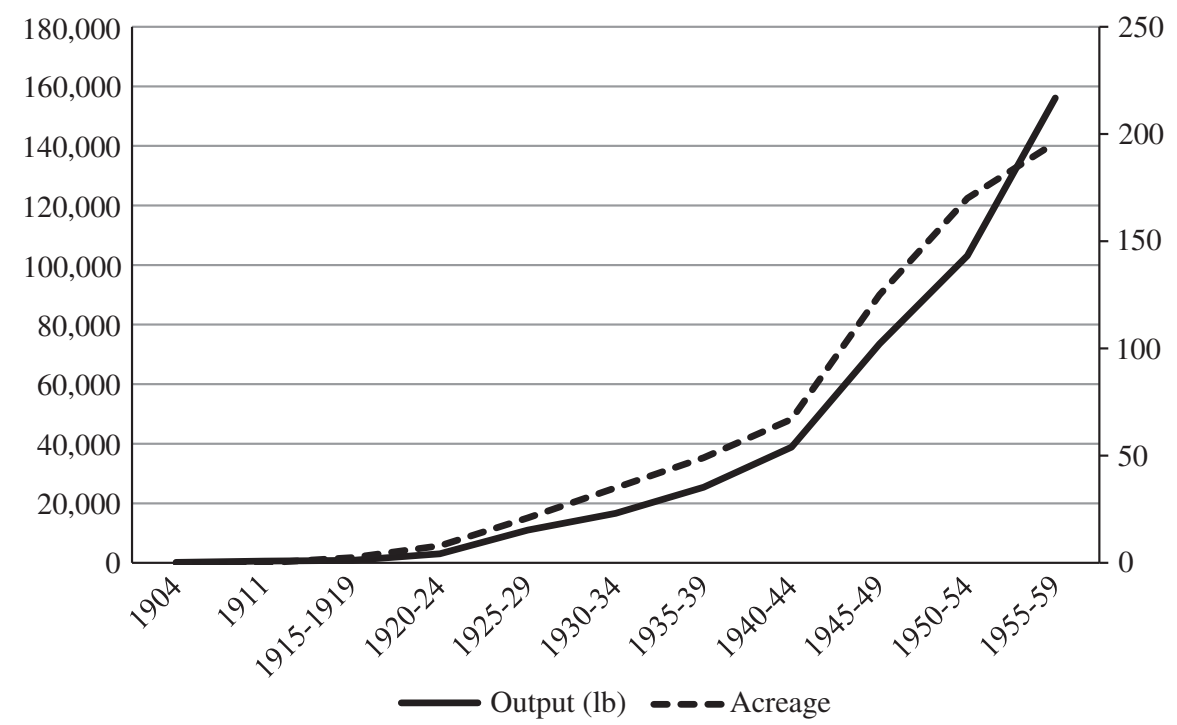

Sources: Phimister (1988, p. 61), 1904-1919 and Mosley (1983), 1920-1959.

agriculture and they obtained better access to, and control over, cheap African labour, both tenant and wage labour (Arrighi 1966; Phimister 1988; Green 2015). In 1897, the colonial authorities decided to create so-called Native Reserves throughout Southern Rhodesia, and in 1909 they introduced a land rent for all Africans living outside the reserves with the intended effect that the inflow of Africans to the Native Reserves began to increase steadily (Punt 1979, p. 29). By 1941 it was estimated that sixty-two out of ninety-eight reserves were «overpopulated»(Phimister 1988, p. 77), making it particularly difficult for African farmers to allocate land to commercial agricultural production (Arrighi 1966, pp. 201-203). African agricultural sales per capita declined and real wages remained more or less stagnant up to the end of the Second World War (Bowden et al. 2008, p. 1065). Meanwhile, the system facilitated white farmers' access to cheap labour.

Meanwhile, in Nyasaland white farmers managed to secure access to large parts of the fertile land in the Shire Highlands, but they continued to operate side by side with Africans growing cash crops on Crown Land and Native Reserves were never established (Green 2013). It even happened that the colonial authorities actively opposed attempts by the settlers to exploit local labour (Green 2013). To be sure, the colonial authorities initially tried to facilitate settler farmers' access to cheap labour by implementing a 
FIGURE 4

TOTAL TOBACCO OUTPUT IN 1,000 METRIC TONNES (LEFT-HAND Y-AXIS) AND THE SHARE PRODUCED BY WHITE FARMERS IN NYASALAND IN PER CENT (RIGHT-HAND Y-AXIS) (1900-1960)

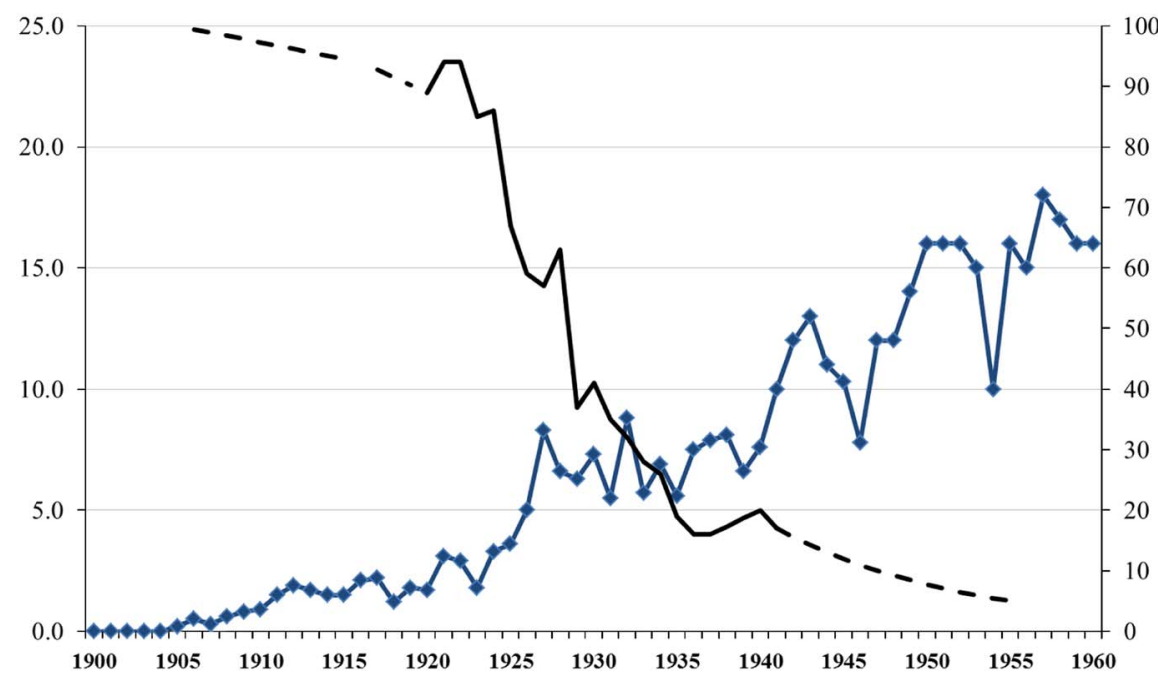

Sources: Tobacco output figures from Mitchell (2007). Share of tobacco crop produced by white farmers from Palmer (1985).

differential tax rate system in 1901 (Bolt and Green 2015), but they abolished this system in $1921^{4}$.

As they were able to pay higher (nominal) wages, European settler farmers in Southern Rhodesia were more successful in attracting migrant labour. In fact, the largest group of immigrant workers came from Nyasaland, while immigrants in Nyasaland mainly came from Portuguese East Africa. The collapse of the European tobacco sector in Nyasaland had little impact on the inflow of Portuguese East Africans, as these migrants went on to the expanding tea sector and/or settled down on African land. Meanwhile, the number of migrants that went to work on the European tobacco farms in Southern Rhodesia steadily increased and by the mid-1950s they constituted more than half of the labour force (Phimister 1988; Chirwa 1997). Indigenous immigration thus facilitated the expansion of tobacco farming in

\footnotetext{
4 Africans who worked on estates paid 3 shillings/month, while the others had to pay 6 shillings/ month. Rural nominal wages were higher in Southern Rhodesia than in Nyasaland throughout the period of investigation despite the more regressive policies in the former case. However, measured as a share of total output, settler farms in Southern Rhodesia faced a lower wage bill from the 1930s onwards (Bolt and Green 2015).
} 
Southern Rhodesia, which by itself was a consequence of its initial success in securing government support.

Why did colonial authorities give full support to the settlers in Southern Rhodesia but not in Nyasaland? A key difference was that lower transportation costs and better trade agreements with South Africa helped the colonial government in Southern Rhodesia to attract skilled settler farmers who, from quite early on, were able to generate profits (Rubert 1998, pp. 5ff). It has been estimated that the cost of shipping tobacco to the coast for Nyasaland's farmers in the 1930s was seven times higher than for farmers in Southern Rhodesia (Palmer 1985, p. 230). Nyasaland - being one of the poorest colonies in British Africa with relatively underdeveloped infrastructure and limited access to regional markets for tobacco - never managed to attract Europeans with sufficient farming skills and capital to establish competitive farms. Most of the tobacco-growing Europeans in Nyasaland were British ex-servicemen with limited experience in farming. Settlers continuously complained about high labour costs and demanded the colonial authorities to take action to ensure adequate supplies of labour by, for example, the re-introduction of the differential tax system (Bolt and Green 2015). However, these demands were not met and after the Second World War most of the resources at the Department of Agriculture instead went to support African agriculture (Green 2007).

This comparative case study thus seems to suggest that differential transfers of human capital determined the success and failure of European tobacco sector in Southern Rhodesia and Nyasaland. Yet, the story is more subtle: European farmer skills just sufficed to ensure political support from the colonial authorities. Precisely, because European human capital and technologies were not superior, political mediation was needed to prevent African farmers to utilise their own skills and technologies, measures that were gradually relaxed in Nyasaland, where settler farmers were insufficiently skilled and equipped to set up profitable tobacco plantations.

\subsection{Cocoa Farming in the Gold Coast and Ivory Coast}

Due to forest frontiers with rich virgin soils producing high yields and high returns - the so-called «forest rent» - cocoa production was attractive to both African farmers and settlers in the West African colonies of the Gold Coast and Ivory Coast. For indigenous farmers the trade-off between the cultivation of cocoa trees and food crops, primarily plantain and coco-yams, was minimal as the latter were planted as shade crops, limiting the spread of weeds on cocoa farms. Intercropping thus saved labour and increased the fertility of the cocoa land (Austin 2005, pp. 304-310). Ghana and Ivory Coast both became world leaders in cocoa exports, although their cocoa booms followed different timelines and development paths, as Figure 5 shows. 
FIGURE 5

COCOA OUTPUT IN GOLD COAST/GHANA AND IVORY COAST IN 1,000 METRIC TONNES (1900-1990)

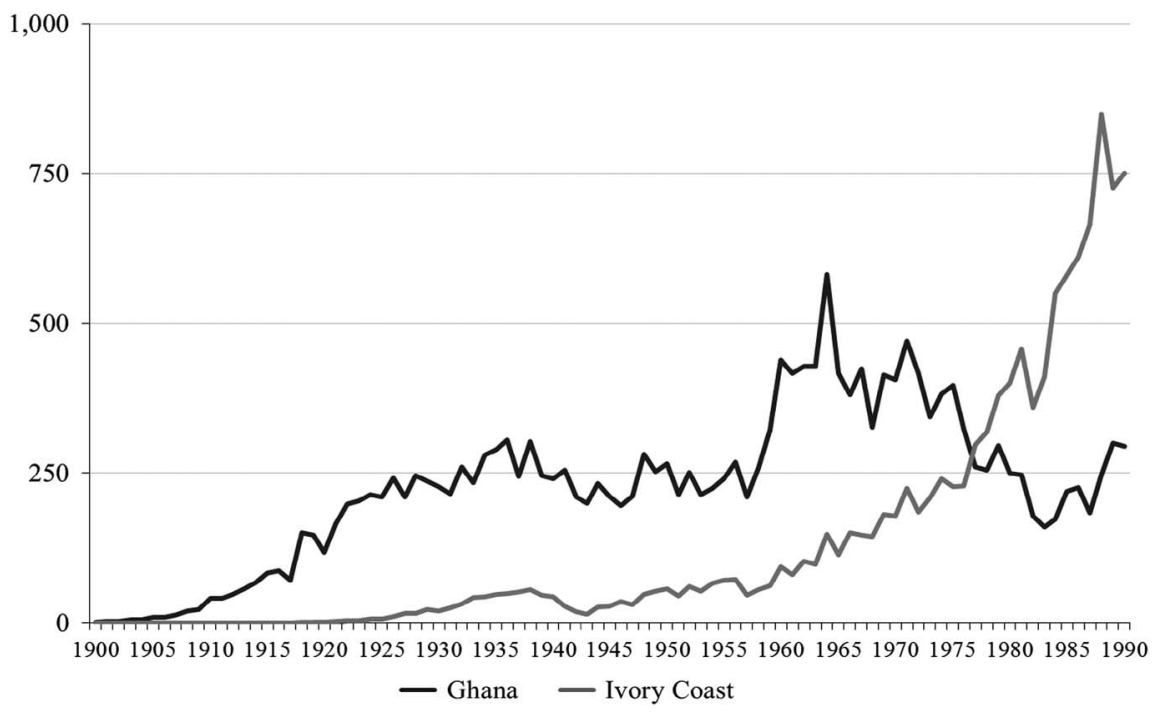

Source: Mitchell (2007, 247-249).

In the Gold Coast the cocoa boom was entirely created by African farmers, and it has been hailed as the most significant success story of commercial agriculture in colonial Africa. In 1882, Gold Coast exported no cocoa beans, but only 19 years later it overtook Brazil as the world's largest exporter with 40,000 tonnes annually. Fifteen years later output had surpassed 200,000 tonnes and in 1936 it topped 300,000 tonnes. After a downturn during the Great Depression and the Second World War, and stagnating output figures during the 1950s, the country experienced a second export boom in the mid-1960s, during the early years of independence.

It took until the 1920s to introduce cocoa in the eastern parts of neighbouring Ivory Coast, which eventually extended towards the central regions. French settlers played a significant role in the early phase of expansion, but it was only with the rise of an indigenous capitalist sector that output really picked up in the 1950s and 1960s (Leonard and Oswald 1995, p. 125; Woods 2003 , p. 645). While the Ivory Coast produced $<100,000$ tonnes of cocoa in 1960 , production soared exponentially after our period of investigation. As Figure 5 shows, Ivory Coast overtook Ghana as the world-leading producer in the late 1970s.

That African farmers would take the lead in the Gold Coast was not certain from the onset of colonial rule. The colonial authorities kept the door 
open to European investors, and this policy was supported by local chiefs who saw an opportunity to benefit from the concessions granted to European planters (Austin 2005, pp. 255-257). Yet, most of these concessions failed to become profitable and were soon abandoned, as British planters proved unable to compete with African cocoa producers having superior skills and intrinsic knowledge of the subtleties of forest agriculture. When African cocoa cultivation took off and profits were consolidated, the colonial authorities began to discourage European settlement. In 1911, Chief Commissioner Fuller declared: «All work in connection with the tilling of the soil must be left to the native of the country» (quoted in Austin 2005, p. 255). After the formal prohibition of European plantations the administration undertook no further attempts at land alienation. Instead, indigenous cocoa farmers in Gold Coast held secure, although indirect, property rights to land, as ownership was established over their cocoa trees.

From 1926 onwards, when the cocoa boom in the Gold Coast was in full swing, the Ivory Coast administration facilitated a small landed elite of mainly French planters in the central and eastern parts of the country. In 1937, there were fourteen European settlers devoting 733 ha to cocoa while African farmers only cultivated 650 ha with cocoa trees (Firmin-Sellers 2000). The small number of European estates, combined with the generally low population density meant that land remained abundant and cheap. As in Kenya and Southern Rhodesia, these planters were well connected to the administration, as they depended on the colonial authorities for their access to local labour (Woods 2003, p. 645). Labour corvée regulations dictated that every adult male had to contribute 12 days of work/year to colonial projects and that the labour demands of settlers had priority over those of indigenous farmers. Yet, despite support from the colonial administration, European planters in the Ivory Coast continued to complain about the lack of labour and the general unreliability of African workers (Chauveau and Richard 1977, pp. 487-488; Firmin-Sellers 2000; Woods 2003, p. 644).

Only in the aftermath of the Second World War, and induced by a more general shift in beliefs regarding universal human rights and a colonial development imperative, did the Ivory Coast government abolish its forced labour programme in 1946. To promote indigenous agriculture, the government put more emphasis on agricultural extension services, including subsidised access to farm inputs and infrastructural improvements. In 19451960, these changes in colonial policy, paired with a surge in world market prices for cocoa, encouraged the rise of a traditional system of lineage production, where indigenous subsistence farmers turned into small-scale cocoa producing capitalist farmers (Hecht 1984, 1985).

Why did the French administration in the Ivory Coast chose to promote settlers' interests, despite the tangible successes of indigenous cocoa production in the British neighbour colony? That both countries shared similar ecological potential for cocoa is beyond doubt, since the expansion of 
cocoa production in Ivory Coast after 1950 was even more impressive than in Gold Coast during the 1900s and 1920s. That European planters failed to tap into this potential can also be explained. Just like the European planters in Gold Coast, they lacked the skills and the appropriate knowledge; it is one thing to coerce physical labour for agricultural production, but it is a very different thing to exploit tacit knowledge and skills through coercion. The answer thus lies in differential African engagement with commercial farming combined with diverging views among colonial officers on strategies of colonial development. The fact that local farmers in Ivory Coast did not demonstrate their engagement in export production as clearly as, for instance, the Asante in Gold Coast, strengthened the colonial government in their pre-conception that European planters were the key to developing the export sector. The policies that were designed to facilitate these settlers held back incipient indigenous initiatives.

The early successes of Ghanaian cocoa farmers had given them a major stake in the colonial economy as well as in colonial state finances (around three-quarters of the total state budget came from trade taxes in the 1920s). They used their handle on colonial policies to influence labour policies, just like European settlers did elsewhere. Low population densities and land abundance made farmers dependent upon various forms of labour coercion, which traditionally had taken the form slavery. British officials invoked the prohibition of slavery as a justification for colonial occupation, but it took 12 years before the colonial authorities banned the buying of slaves and another 22 years before human pawning became illegal. Despite continued pressure from the Colonial Office in London, local authorities were reluctant to prohibit slavery, as that could endanger the cocoa boom and lead to political conflicts with the cocoa farmers (Austin 2005, pp. 270ff). The delay enabled Africans to accumulate sufficient capital in the initial phase of expansion to gradually replace their slaves with migrant labour; first as wage labourers, but in the postwar period also working under share-cropping contracts. Meanwhile, «foreign» African groups were allowed to acquire virgin land in the forest. These changes in labour contracts signalled the ability of African cocoa farmers to maintain control over labour in a changing economy (Austin 2005, pp. 317ff).

Just as in the Gold Coast, systems of share-cropping evolved in Ivory Coast in the 1950s with smallholders hiring farmhands on a semi-contractual basis. Migrant labourers, originating from all over West Africa, were paid in kind or cash, or were allowed to sell a portion of their produce. Eventually, they were given access to their own plot of land. Temporary contractual migrant labour also existed, especially among the larger producers. After independence, mass immigration boosted cocoa production in absolute terms, and also aided the ever-struggling settler sector (Hecht 1985; Woods 2004, p. 229). This boom turned Ivory Coast into the prime example of an independent African country that managed to avoid economic stagnation and political instability during the 1970s and 1980s (Nugent 2012). 
In sum, in both cases initial attempts at colonial settlement failed because European knowledge and technology of cocoa cultivation proved inferior to indigenous knowledge of local ecologies and cultivation techniques. In the Gold Coast the superiority of local knowledge was so obvious to the colonial authorities that they soon allowed the more efficient and flexible African production systems to expand. The Ivory Coast administration favoured settlers' interests not because of their perceived technological superiority, but because indigenous commercial production was insignificant when the French declared control over the territory. Despite political back-up, the European planters never managed to secure sufficient African labour and they proved unable to compete with African cocoa farmers in the Gold Coast. In the post-war period government policy in Ivory Coast shifted towards structural support for indigenous cocoa farms, which facilitated the emergence of a class of African small-scale capitalist farmers with sufficient control over land and labour to flourish. Hence, the historical process of failed settlement was endogenous to African agency, to superior African knowledge and skills and to the failure of European planters to successfully exploit African labour, skills and knowledge.

\section{CONCLUSION}

In an influential strand of economics literature the history of European imperialism is being conceptualised as an exogenous event that is supposed to have «determined» a substantial share of present-day global income differences. The meta-narrative of these studies contends that colonial settlement is the result of conditions that are exogenous to the settlement process as such, and assumes a direct causal link running from the presence of European settlers, to a unilateral transfer of growth-promoting technology, knowledge and institutions, to higher levels of long-term economic development.

In this paper we have argued that this literature overlooks a fundamental part of the historical complexity of colonial settlement processes in Sub-Saharan Africa and beyond. None of the three comparative case studies that we have conducted supports the idea that historical causality worked in this direction, neither do they give much reason to believe that the success or failure of colonial settlement was determined by factors that were exogenous to the process of settlement. On the contrary, our case studies suggest that settlement processes were driven by the continuous competition between European settlers and African farmers over productive resources, the allocation of which was varyingly mediated by the colonial authorities. The path of European settlement was therefore as much determined by European transfers of technology, knowledge and institutions in the early phases of colonisation, as it was determined by African indigenous knowledge and African responses to new market opportunities. Studies that explain present-day 
global inequality by focussing exclusively on the European contribution to global development are thus bound to miss a crucial part of the equation: the interaction inherent to these colonial encounters.

In this interaction, so we have argued, the control over land, and above all the control over labour, was the key factor of success. In the African cases we studied, settler farmers' capacity to control land and labour depended on the applicability of European technology and knowledge to local ecological conditions as well as the time and leverage they were granted by the authorities to turn their farms into profitable businesses. This capacity was strongly influenced, in turn, by the aspirations and cunningness of local African farmers, who were usually more knowledgeable and efficient in the cultivation of tropical cash crops in local ecologies.

In all of our six cases the early ambition of newly established colonial authorities was to attract European settlers that would form the backbone of the colonial economy, and the fiscal revenues that were needed to extend the colonial state. In the case of Ghana the colonial authorities had already witnessed the success of African commercial production in the late $19^{\text {th }}$ century. These lowered the economic and political incentives of the colonial administration to encourage European settlement. In the five other cases the stereotypical views of the inefficient small-scale African farmers held by colonial officials proved harder to dissolve. The demand of settlers for government support in the recruitment of African labour was granted with varying degrees of coercion, ranging from restrictions on African cash-crop production, forced labour, land alienation, the establishment of Native Reserves and the introduction of direct taxes to be paid in cash.

However, the long-term success of settler agriculture required sustained political support, and this proved far more difficult. The turbulent interwar period made the future of settler agriculture uncertain and in most places African involvement in cash-crop production expanded despite restrictive government policies. The Great Depression dealt a major blow to the European farming sector, creating the need to revise fiscal and labour market policies. After the Second World War, only in Southern Rhodesia the colonial authorities continued to offer full-fledged support to the European farming sector. In the other cases, attempts to transfer European knowledge, technology and institutions did not result in a sustained path of economic growth and, consequently, European settlement in Sub-Saharan Africa remained confined to minorities facing insecure futures. Settlement was thus as much a consequence, as it was a cause of European transfers of technology, human capital and institutions.

\section{REFERENCES}

Acemoglu, D.; Johnson, S., and Robinson, J. A. (2001): «The Colonial Origins of Comparative Development: An Empirical Investigation». American Economic Review 91 (5), pp. 1369-1401. 
Acemoglu, D.; Johnson, S., and Robinson, J. A. (2002): «Reversal of Fortune: Geography and Institutions in the Making of the Modern World Income Distribution». Quarterly Journal of Economics 117 (4), pp. 1231-1294.

Acemoglu, D., and Robinson, J. A. (2010): «Why is Africa Poor?». Economic History of Developing Regions 25 (1), pp. 21-50.

Acemoglu, D., and Robinson, J. A. (2012): Why Nations Fail. The Origins of Power, Prosperity and Poverty. New York: Crown Publishers.

Amin, S. (1972): "Underdevelopment and Dependence in Black Africa. Origins and Contemporary Forms». Journal of Modern African Studies 10 (4), pp. 503-524.

Anderson, D. (1984): «Depression, Dust Bowl, Demography, and Drought: The Colonial State and Soil Conservation in East Africa During the 1930s». African Affairs 83 (332), pp. 321-343.

Anderson, D. (2000): «Master and Servant in Colonial Kenya». Journal of African History 41 (3), pp. 459-485.

Anderson, D., and Throup, D. (1985): «Africans and Agricultural Production in Colonial Kenya: The Myth of the War as the Watershed». The Journal of African History 26 (4), pp. 327-345.

Arrighi, G. (1966): «The Political Economy of Rhodesia». New Left Review 39, pp. 35-65.

Austin, G. (2005): Labour, Land and Capital in Ghana - From Slavery to Free Labour in Asante, 1807-1956. Rochester, NY: Rochester University Press.

Austin, G. (2008): «The «Reversal of Fortune» Thesis and the Compression of History: Perspectives from African and Comparative Economic History». Journal of International Development 20, pp. 996-1027.

Austin, G. (2015): "The Economics of Colonialism in Africa», in M. Célestin, and L. Justin Yifu (eds), The Oxford Handbook of Africa and Economics: Context and Concepts. Oxford: Oxford University Press, pp. 522-535.

Austin, G., and Sugihara, K. (eds) (2013): Labour-Intensive Industrialization in Global History. New York: Routledge.

Banerjee, A. V., and Duflo, E. (2014): «Under the Thumb of History? Political Institutions and the Scope for Action». Annual Review of Economics 6 (1), pp. 951-971.

Barlow, C., and JAYASURIJA, S. K. (1986): «Stages of Development in Smallholder Tree Crop Agriculture». Development and Change 17 (4), pp. 635-658.

BAYly, C. (2008): «Indigenous and Colonial Origins of Comparative Economic Development: The Case of Colonial India and Africa». Policy Research Working Papers, 4474. Washington DC: World Bank.

Bolt, J., and Green, E. (2015): «Was the Wage Burden Too Heavy? - Settler Farming, Wages and the Profitability of Settler Agriculture in Colonial Malawi, C. 1900-1960». Journal of African History 56 (2), pp. 217-238.

Bowden, S.; Chiripanhura, B., and Mosley, P. (2008): «Measuring and Explaining Poverty in Six African Countries: A Long-Period Approach». Journal of International Development 20 (8), pp. 1049-1079.

Carney, J. A., and Rosomoff, R. N. (2011): In the Shadow of Slavery. Africa's Botanical Legacy in the Atlantic World. Berkeley, CA: University of California Press.

Chauveau, J. P., and Richard, J. (1977): «Une «Périphérie Recontrée»: À Propos D'un Système Local D'économie de Plantation en Côte d'Ivoire». Cahiers d'Études africaines 68 (17-4), pp. 485-523.

CHIRwA, C. W. (1997) "The Garden of Eden: Sharecropping on the Shire Highlands Estates, 1920-1945», in Jeeves and Crusch (eds), White Farms, Black Labor - The State and Agrarian Change in Southern Africa, 1910-1950, Oxford: James Currey, 265-280. 
Cooper, F. (2002): Africa Since 1940. The Past of the Present. Cambridge MA: Cambridge University Press.

CuRTis, K. R. (2003): «Smaller is Better: A Consensus of Peasants and Bureaucrats in Colonial Tanganyika», in W. G. Clarence-Smith, and S. Topik (eds), The Global Coffee Economy in Africa, Asia and Latin America 1500-1989. Cambridge: Cambridge University Press, pp. 312-334.

De Zwart, P. (2011): «South African Living Standards in Global Perspective, 1835-1910». Economic History of Developing Regions 26 (1), pp. 49-74.

Diamond, J. (1998): Guns, Germs and Steel. A Short History of Everybody for the Last 13,000 Years. London: Vintage.

Easterly, W. (2006): The White Man's Burden. Why the West's Efforts to Aid the Rest have Done So Much Ill and So Little Good. Oxford: Oxford University Press.

EASTERly, W., and Levine, R. (2012): «The European Origins of Economic Development». NBER Working Paper no. 18162. Cambridge, MA: National Bureau of Economic Research.

Eckert, A. (2003): «Comparing Coffee Production in Cameroon and Tanganyika, C. 1900 to 1960s: Land, Labour and Politics», in W. G. Clarence-Smith, and S. Topik (eds), The Global Coffee Economy in Africa, Asia and Latin America 1500-1989. Cambridge: Cambridge University Press, pp. 286-311.

Elliott, J. H. (2006): Empires of the Atlantic World. Britain and Spain in America 14921830. New Haven, CT: Yale University Press.

Eltis, D. (2000): The Rise of African Slavery in the Americas. Cambridge, UK: Cambridge University Press.

Ferguson, N. (2002): Empire: The Rise and Demise of the British World Order and the Lessons for Global Power. New York, NY: Basic Books.

Firmin-Sellers, K. (2000): «Institutions, Context, and Outcomes: Explaining French and British Rule in West Africa». Comparative Politics 32 (3), pp. 253-272.

Fourie, J., and von Fintel, D. (2014): "Settler Skills and Colonial Development: The Huguenot Wine-Makers in Eighteenth-Century Dutch South Africa». Economic History Review 67 (4), pp. 932-963.

Frankema, E. (2011): «Colonial Taxation and Government Spending in British Africa, 1880-1940: Maximizing Revenue or Minimizing Effort?». Explorations in Economic History 48 (1), pp. 136-149.

Frankema, E. (2012): "The Origins of Formal Education in Sub-Saharan Africa: Was British Rule More Benign?». European Review of Economic History 16 (4), pp. 335-355.

FranKEMA, E. (2015): «Labour-Intensive Industrialization in Global History - A Review Essay». Economic History of Developing Regions 30 (1), pp. 44-67.

Frankema, E., and van WaiJenburg, M. (2012): "Structural Impediments to African Growth? New Evidence from Real Wages in British Africa, 1880-1965». Journal of Economic History 72 (4), pp. 895-926.

Gallego, F. A., and Woodberry, R. (2010): "Christian Missionaries and Education in Former African Colonies: How Competition Mattered». Journal of African Economies 19 (3), pp. 294-329.

Gardner, L.A. (2012): Taxing Colonial Africa: The Political Economy of British Imperialism. Oxford: Oxford University Press.

Green, E. (2007): «Modern Agricultural History in Malawi: Perspectives on Policy Choices». African Studies Review 50 (3), pp. 143-167.

GreEN, E. (2013): «Land Concentration, Institutional Control and African Agency — Growth and Stagnation of European Tobacco Farming in Shire Highlands, c 1900-1940», 
in E. Hillbom, and P. Svensson (eds), Agricultural Transformations and Global History. London: Routledge, pp. 229-262.

Green, E. (2015): «The Development of Agrarian Capitalism and Settler Farming in Southern Rhodesia Revisited: Estimating the Role of Tenant Labour». Paper presented at the World Economic History Congress, Kyoto (August 3-7).

Haviland, W. E. (1953): "The Rise of the African Tobacco Industry in Nyasaland and its Production Problems». The South African Journal of Economics 22 (2), pp. 141-152.

HaviLand, W. E. (1954): «The Use and Efficiency of African Labour in Tobacco Farming in Southern Rhodesia». The Canadian Journal of Economics and Political Science 20 (1), pp. 100-106.

Heснт, R. M. (1984): «The Transformation of Lineage Production in Southern Ivory Coast, 1920-1980». Ethnology 2 (4), pp. 261-277.

Hecht, R. M. (1985): «Immigration, Land Transfer and Tenure Changes in Divo, Ivory Coast, 1940-1980». Africa 55 (3), pp. 319-336.

Hopkins, A. G. (2009): «The New Economic History of Africa». Journal of African History 50 (2), pp. 155-177.

Hyde, D. (2009): «Paying for the Emergency by Displacing the Settlers: Global Coffee and Rural Reconstruction in Late Colonial Kenya». Journal of Global History 4 (1), pp. 81-103.

ILIFFE, J. (1979): A Modern History of Tanganyika. Cambridge: Cambridge University Press.

Kirk-Greene, A. H. M. (1980): "The Thin White Line: The Size of the British Colonial Service in Africa». African Affairs 79 (314), pp. 25-44.

KLeIN, H. S. (2010): The Atlantic Slave Trade, new edn. Cambridge: Cambridge University Press.

Law, R. (2013): «There's Nothing Grows in the West Indies But Will Grow Here»: Dutch and English Projects of Plantation Agriculture on the Gold Coast, 1650s-1780s», in R. Law; S. Schwarz, and S. Strickrodt (eds), Commercial Agriculture, the Slave Trade and Slavery in Atlantic Africa. Woodbridge, Suffolk; Rochester, NY: Boydell \& Brewer, pp. 116-137.

Leonard, E., and Oswald, M. (1995): «Cocoa Smallholders Facing a Double Structural Adjustment in Côte D'Ivoire: Responses to a Predicted Crisis», in F. Ruf, and P. S. Siswoputranto (eds), Cocoa Cycles - The Economics of Cocoa Supply. Cambridge: Woodhead Publishing Ltd, pp. 125-177.

Maddison, A. (2010): «Historical Statistics on World Population, GDP and Per Capita GDP, 1-2008 AD». Available at http://www.ggdc.net/maddison/

Makana, N. E. (2009): «Metropolitan Concern, Colonial State Policy and the Embargo on Cultivation of Coffee by Africans in Colonial Kenya: The Example of Bugoma District, 1930-1960». History in Africa 38, pp. 315-329.

Mitchell, B. R. (2007): International Historical Statistics: Africa, Asia \& Oceania, 1750 2005, 5th edn. Basingstoke: Palgrave Macmillan.

Mkandawire, T. (2010): «On Tax Efforts and Colonial Heritage in Africa». Journal of Development Studies 46 (10), pp. 1647-1669.

Moradi, A. (2008): «Confronting Colonial Legacies: Lessons from Human Development in Ghana and Kenya, 1880-2000». Journal of International Development 20, pp. 1107-1120.

Mosley, P. (1983): The Settler Economies: Studies in the Economic History of Kenya and Southern Rhodesia, 1900-1963. Cambridge: Cambridge University Press.

NiemeiJer, D. (1996): «The Dynamics of African Agricultural History: Is It Time for a New Development Paradigm?». Development and Change 27 (1), pp. 87-110. 
Nugent, P. (2012): Africa Since Independence, 2nd edn. New York: Palgrave Macmillan. Nunn, N. (2010): «Religious Conversion in Colonial Africa». American Economic Review: Papers \& Proceedings 100, pp. 147-152.

OrR, A. (2000): “'Green Gold”? Burley Tobacco, Smallholder Agriculture, and Poverty Alleviation in Malawi». World Development 28 (2), pp. 347-363.

Palmer, R. (1985): «White Farmers in Malawi: Before and After the Depression». African Affairs 83, pp. 211-245.

Phimister, I. (1988): An Economic and Social History of Zimbabwe, 1890-1948: Capital, Accumulation and Class Struggle. Harlow: Longman.

Punt, E. (1979): «The Development of African Agriculture in Southern Rhodesia with Particular Reference to the Interwar Years». Department of History, University of Natal, Unpublished Master's Thesis.

Putterman, L., and Weil, D. N. (2010): «Post-1500 Population Flows and the Long Run Determinants of Economic Growth and Inequality». Quarterly Journal of Economics 125 (4), pp. 1627-1682.

Rodney, W. (1972): How Europe Underdeveloped Africa. London: Bogle-L'Ouverture Publications.

Rostow, W. W. (1960): The Stages of Economic Growth. A Non-Communist Manifesto. Cambridge, UK: Cambridge University Press.

Rubert, S. C. (1998): A Most Promising Weed - A History of Tobacco Farming and Labor in Colonial Zimbabwe, 1890-1945. Athens, OH: Ohio University Press.

Schutz, B. M. (1973): «European Population Patterns, Cultural Persistence and Political Change in Rhodesia». Canadian Journal of African Studies 7 (1), pp. 3-25.

Seibert, G. (2013): «São Tomé and Príncipe: The First Plantation Economy in the Tropics», in R. Law; S. Schwarz, and S. Strickrodt (eds), Commercial Agriculture, the Slave Trade and Slavery in Atlantic Africa. Woodbridge, Suffolk; Rochester, NY: Boydell \& Brewer, pp. 54-78.

SPEAR, T. (1997): Mountain Farmers: Moral Economies of Land and Agricultural Development in Arusha and Meru. Oxford: James Currey.

Storm, S. (2013): «Why the West Grew Rich and the Rest Did Not, or How the Present Shapes Our Views of the Past». Development and Change 44 (5), pp. 1181-1206.

Tosh, J. (1980): «The Cash-Crop Revolution in Tropical Africa: An Agricultural Reappraisal». African Affairs 79 (314), pp. 79-94.

WoodberRy, R. (2012): «The Missionary Roots of Liberal Democracy». American Political Science Review 106 (2), pp. 244-274.

Woods, D. (2003): «The Tragedy of the Cocoa Pod: Rent-Seeking, Land and Ethnic Conflict in Ivory Coast». The Journal of Modern African Studies 41 (4), pp. 641-655.

Woods, D. (2004): «Predatory Elites, Rents and Cocoa: A Comparative Analysis of Ghana and Ivory Coast». Commonwealth and Comparative Politics 42 (2), pp. 224-241.

Young, C. (1994): The African Colonial State in Comparative Perspective. New Haven, CT: Yale University Press. 